С. О. Гавриловський,

аспірант, завідувач навчальної лабораторії ННІ іноземної філології (Житомирський державний університет імені Івана Франка) temp@nniif.org.ua ORCID: 0000-0002-0099-4477

\title{
НАУКОВО-ДОСЛІДНА ДІЯЛЬНІСТЬ МАЙБУТНІХ КЕРІВНИКІВ ЗАГАЛЬНООСВІТНІХ НАВЧАЛЬНИХ ЗАКЛАДІВ У ПРОЦЕСІ МАГІСТЕРСЬКОЇ ПІДГОТОВКИ: ПОШУКИ НОВИХ МОЖЛИВОСТЕЙ
}

На основі вивчення теоретичних джерел з проблеми дослідження нами представлено оглядовий аналіз стану науково-дослідної діяльності майбутніх керівників загальноосвітніми навчальними закладами $в$ умовах навчання в магістратурі; визначено та наведено напрями, завдання, етапи організаційнопедагогічного супроводу навчальної та науково-дослідної діяльності; виділено компоненти ефективного здійснення науково-дослідної діяльності магістрантів; встановлено значення і вплив особистості наукового керівника на результативність науково-дослідної діяльності майбутніх керівників; $з$ викладених у статті суджень стосовно досліджуваної проблеми, нами було окреслено ряд важливих закономірностей.

Ключові слова: науково-дослідна діяльність, науковий керівник, загальноосвітній навчальний заклад, магістрант, управління.

Постановка проблеми. Змінюючи пріоритети функціонування освітнього простору з традиційної, знаннєвої моделі розвитку на гуманітарно-особистісну, з орієнтацією на вихованні різнобічно розвиненої особистості, сучасна система вищої освіти орієнтована на визнання унікальної цінності кожної особистості, створення атмосфери творчості та взаєморозуміння між суб'єктами навчального процесу. Саме тому особливої значущості набуває підготовка майбутніх управлінців загальноосвітніх навчальних закладів (ЗН3) до науково-дослідної діяльності в умовах навчання в магістратурі. Адже від особистості керівника залежить ефективність роботи всіх підсистем навчального закладу. Одним з шляхів досягнення цієї мети являється ефективна організація цієї роботи у вищих навчальних закладах, які функціонують в рамках поєднання навчальної та науково-дослідної діяльності студентів на всіх етапах їхнього навчання.

У змісті освітньо-кваліфікаційного рівня вищої освіти "Магістр" виокремлено дві компоненти. Освітня, яка передбачає їхню підготовку, перепідготовку та підвищення кваліфікації. Наукова, завданнями якої визначено проведення фундаментальних і прикладних досліджень, отримання нових знань як основи інноваційних розвідок університетського, регіонального і всеукраїнського рівнів. Тобто, в структурі інноваційної інфраструктури вищого навчального закладу можемо виокремити наступні компоненти: оформлення і супровід впровадження наукових досліджень, взаємодію на основі інтеграції корпоративних та наукових зацікавлень науковців, авторських інноваційних проектів, викладачів, студентів і замовників, які разом реалізують інноваційні технології на всіх етапах їхнього супроводу: замовлення - створення - експертиза - апробація - презентація інноваційного продукту.

У Законі України "Про вищу освіту" зазначено, що держава створює умови для "...поєднання освіти 3 наукою та виробництвом 3 метою підготовки конкурентоспроможного людського капіталу для високотехнологічного та інноваційного розвитку країни, самореалізації особистості, забезпечення потреб суспільства..." [1]. У розділі VI - "Вищі навчальні заклади" - передбачено створення університетів дослідницького типу. У ньому визначено, що "національному вищому навчальному закладу, що забезпечує проривний розвиток держави в певних галузях знань відповідно до моделі поєднання освіти, науки та інновацій, сприяє іiі інтеграції у світовий освітньо-науковий простір, має визнані наукові здобутки, може надаватися статус дослідницького університету" [1, ст. 30, п. 1].

Викладені вище положення підтверджуються виконанням завдань, сформульованих у Законі України "Про наукову і науково-технічну діяльність" і в "Положенні про дослідницький університет", серед яких - "...ініціювання і замовлення прогнозних та форсайтних досліджень у галузі науки, технологій, інновацій, організації та проведення наукової експертизи рішень центральних органів виконавчої влади, що стосуються наукової сфери...", акцентовано увагу на розробленні та впровадженні в навчальний процес новітніх інформаційних технологій і засобів навчання 3 метою підготовки фахівців 3 питань інноваційного розвитку; реалізації інноваційних програм підготовки наукових і науково-педагогічних кадрів для університетів, наукових установ, наукоємних виробництв [2, ст. 20, п. 11].

У державній національній програмі "Освіта" ("Україна ХХІ століття") виокремлено такі пріоритетні напрями реформування системи науково-дослідної діяльності: інтеграція академічної, вузівської й галузевої науки; докорінна зміна системи організації, фінансування, управління та стимулювання науково-дослідної діяльності студентів; створення умов для ефективного використання наукового 
потенціалу освітньої галузі; свобода творчості вчених; започаткування конкурсного відбору наукових програм і проектів [3].

Аналіз останніх досліджень і публікацій. Історичний екскурс у вивчення проблеми нашого дослідження дає можливість констатувати, що джерелознавча база представлена як фундаментальними дослідженнями відомих вітчизняних науковців, так і окремими студіями сучасних дослідників.

Досвід проведення науково-дослідної роботи студентами вищих навчальних закладах свідчить, що увагу науковців зосереджено навколо питань теорії та методології наукових досліджень (О. Вернидуб, Р. Набока, О. Самсонова); концептуальні засади управління науково-дослідною діяльністю студентів вищих навчальних закладів економічного профілю проаналізовано у низці наукових розвідок В. Степашка.

Науково-дослідну діяльність студентів у творчих колективах, як методологічну основу підвищення якості підготовки фахівців, висвітлено в публікаціях Гр. Луценка, Г. Луценка; психологічні аспекти здійснення науково-дослідної роботи студентів вищих навчальних закладів в умовах реалізації завдань Болонської конвенції висвітлено в публікації Л. Сатановської, принципи та етапи творчого становлення майбутнього фахівця сформульовано в роботах І. Ромащенко, Н. Уйсімбаєвої; організаційно-методичні аспекти науково-дослідної роботи проаналізовано і викладено у спільній розробці Н. Кушнаренко і В. Шейко.

Враховуючи той факт, що досліджувані проблеми мають багаторівневий та різноплановий характер, пошуки нових можливостей проведення науково-дослідної роботи студентами-магістрами уявляються нам актуальним за змістом й функціональними характеристиками питанням.

Саме тому організація науково-дослідної діяльності студентів в умовах магістратури в руслі визначених орієнтирів становить мету нашої розвідки, а саме: виявлення та вивчення нових напрямів проведення науково-дослідної роботи. Завдання роботи, мотивовані поставленою метою, передбачають наступне: окреслити етапи організаційно-педагогічного супроводу наукових досліджень, що інтегрують практичні проблеми управління в загальноосвітніх навчальних закладах й наукові розвідки, що проводяться в рамках планових науково-дослідних проектів вищих навчальних закладів; визначити значення і вплив особистості наукового керівника на творче застосування набутого досвіду в науководослідній діяльності студентів-магістрів.

Виклад основного матеріалу. Основою навчального процесу у вищих навчальних закладах $\epsilon$ цілеспрямована і контрольована аудиторна, позааудиторна (самостійна підготовка слухачів до занять), вибір навчального матеріалу, його самостійне вивчення, організація діалогового обміну між викладачем і тими, хто навчається. Вона дає можливість враховувати індивідуальні здібності, потреби, темперамент слухачів, які опановують навчальну програму. Принцип поєднання навчання з науковою діяльністю стає дієвим чинником у формуванні висококваліфікованого керівника. Встановлено, що розвиток самостійної науково-дослідної діяльності студентів передусім має відбуватися під час навчального процесу, що позитивно впливатиме на формування професійних й індивідуальних характеристик майбутніх керівників ЗН3 [4: 89].

Усвідомлюючи значення науково-дослідної діяльності студентів (НДДС) для подальшого професійного й особистісного становлення майбутнього керівника загальноосвітнього навчального закладу, оптимізація і диверсифікація напрямів ефективної педагогічної освіти, підвищення професійної компетентності певною мірою спрямовують зусилля науковців на проведення наукових розвідок, об'єктом яких стає науково-дослідна діяльність студентів, пошук і апробація нових технологій, що суттєво підвищують їі результативність.

Обгрунтовуючи зміст організації і характер НДДС, В. Шейко та Н. Кушнаренко визначають такі основні напрями іiі проведення: навчально-дослідна діяльність як невід'ємна складова навчального процесу, науково-дослідна діяльність, яку студенти проводять поза навчальним процесом в рамках наукових гуртків, проблемних груп, перекладацьких та інформаційних студій, наукових шкіл; організації і проведення конференцій, конкурсів, виставок-ярмарок найкращих студентських робіт) [5].

За словами В. Степашка, науково-дослідна робота "...є самостійною творчою діяльністю студентів, яка вимагає спрямованої самоорганізації, створення ситуації додаткової орієнтації на вирішення проблемних завдань" [6:34].

Управління науково-дослідною діяльністю студентів, спрямоване на розвиток творчих здібностей студентів, формування компетентності у процесі створення організаційних, педагогічних умов, самоорганізацію для забезпечення саморозвитку. Також він зазначає, що управлінські дії необхідно спрямувати на контроль та аналіз результатів, а науково-дослідну діяльність - на природний розвиток студентів [6: 37].

Як зазначає О. Рогозіна, за допомогою правильно організованої наукової роботи можна вирішувати такі завдання навчальної діяльності: застосовувати отримані знання для вирішення конкретних дослідних завдань; розвивати навички наукових досліджень; формувати вміння вільно орієнтуватися в літературі того або іншого напряму, виступати з доповіддю чи лекцією; формувати уміння узагальнювати на 
науково-теоретичному рівні окремі факти, явища, проблеми; оволодівати методами наукового пізнання, дослідними вміннями i навичками (систематизувати, порівнювати, співставляти, визначати закономірності й тенденції в процесах, явищах та емпіричному матеріалі досліджень) [7].

Враховуючи наведені положення, можна сформулювати основні напрями досліджень вітчизняних науковців в означеному сегменті: зміст і структура науково-дослідної діяльності студентів, проблемноорієнтований і комплексний характер впливу науково-дослідної діяльності на особистість студента, на становлення його теоретичних знань й дослідних умінь.

Особливої уваги заслуговує питання проведення науково-дослідної діяльності студентами магістратури. Магістратура готує фахівців високого рівня і $є$ заключною сходинкою вищої освіти тому і вимоги до організації науково-дослідної діяльності магістрантів, розвитку вмінь та навичок такої діяльності, якості її вихідних продуктів мають свої особливості [8: 182]. Магістр - це освітній ступінь, що здобувається на другому рівні вищої освіти та присуджується вищим навчальним закладом у результаті успішного виконання здобувачем вищої освіти відповідної освітньої програми. Ступінь магістра здобувається за освітньо-професійною або за освітньо-науковою програмою. Освітньо-наукова програма магістра обов'язково включає дослідну (наукову) компоненту обсягом не менше 30 відсотків [1, ст. 5, п. 5].

Підготовка магістрів у системі вищої освіти, на думку дослідника А. Балюк, спрямована на створення умов для творчого розвитку обдарованої особистості та підготовку фахівців за одним із функціональних напрямів діяльності: науково-дослідним (творчим), науково-педагогічним, управлінським [9: 8-9].

Науково-дослідна діяльність магістрантів грунтується на завданнях навчального процесу. Проаналізувавши навчальні програми магістратури з предметів педагогічного циклу, Л. Ніколаєва робить висновок, що під час підготовки до практичних занять магістранти завжди проводять науководослідну діяльність. Вона полягає у самостійному визначенні самої проблематики досліджень, вивченні наукових джерел інформації і в залежності від виду науково-дослідної діяльності, подальшому дослідженні та оформленні результатів [8: 182].

Досить гармонійним і взаємодоповнюючим, вважає В. Берека, "...в концептуальному плані ... поєднувати у своій діяльності соціальні і особистісні інтереси, індивідуальні і колективні дії, традиційні і нові елементи педагогічного процесу засвоєння знань і розвиток особистості, алгоритмізацію і творчість, живе спілкування учасників навчально-виховного процесу і роботу з комп'ютером, логічне і образноемоційне, індукцію і дедукцію, гуманітарне і природничо-наукове, лінійну і концентричну побудову освітніх програм, автономність і підпорядкованість" [10: 9].

Отже, підсумовуючи результати педагогічних рефлексій авторів, можна стверджувати: розвиток самостійної науково-дослідної діяльності студентів передусім має відбуватися під час навчального процесу, що позитивно впливатиме на формування професійних й індивідуальних характеристик майбутніх керівників ЗНЗ.

Вивчення наукових джерел 3 означеної проблематики уможливлює формулювання наступного твердження: більшість із зарахованих до навчання в магістратурі вже мають власний досвід управлінської діяльності в закладах освіти. Це безпосередньо впливає на вибір місця проходження практики й залежить від професійної зацікавленості та специфіки основної діяльності майбутнього керівника. Відповідно, сам майбутній управлінець, застосовуючи досвід, накопичений під час навчання і проведення науково-дослідних локальних проектів, самостійно формує та систематизує зібрані факти, підтверджуючи їх необхідною аргументацією і доводячи їх наукову і практичну цінність. Так поступово встановлюються взаємозв'язки наукового й інформаційного супроводу впровадження та оформлення результатів магістерських досліджень, котрі, за замовчуванням, можна розглядати як синергетичний підхід до проблеми впровадження наукових ініціатив в реальну освітню практику. Адже саме таке нешаблонне бачення і вирішення конкретних управлінських проблем в загальноосвітніх навчальних закладах проходить під керівництвом науковців, що суттєво скорочує дистанцію між виникненням ідеї та іiі втіленням. До того ж результати дослідження наведено у відповідній звітній та поточній документації (звіт, щоденник проведення практики), в подальшому можуть стати темами виступів на конференціях, написання статей із питань управління у сфері освіти.

Звичайно, ми не маємо на увазі розв'язання проблем на макрорівні, але уміння визначати проблемні ситуації, виділяти етапи проведення наукового дослідження, презентувати результати його проведення підтверджує рівень володіння студентом-магістром дослідними вміннями, відповідними компетенціями.

Очевидно, що означений нами напрям є перспективним в наступних вимірах:

- на рівні вищого навчального закладу - захист магістерської роботи, важливою складовою якого $є$ проведення наукового дослідження, в змістовій частині котрого сконцентровано шляхи вирішення питань навчальних закладів регіонального рівня, підтверджує висловлену нами думку про можливість і доцільність проведення наукових розвідок тих управлінських проблем, які існують в освітніх закладах;

- на мотиваційному - вміння досягати поставлених завдань. Успішний захист магістерської роботи $\epsilon$ професійним і водночас особистісним досягненням магістра, що синхронізується з соціальною його 
значимістю.

Для досягнення високих результатів визначальною (якщо не головною) $є$ теза про роль наукового керівника в системі відношень: "магістрант - керівник магістерської роботи". За характером відносин можна виокремити комплекс необхідних особистісних і ділових якостей наукового керівника:

- концентрація уваги на основних аспектах дослідження;

- входження майбутнього управлінця в науково-пошукову діяльність;

- підтримка майбутнього керівника на кожному з етапів проведення дослідження;

- допомога в неоднозначних управлінських ситуаціях.

Практика управління сучасним ЗНЗ неможлива без володіння на достатньому рівні інформаційними технологіями підтримки процесу управління з метою оформлення власних ідей, планування, організації, контролю навчально-виховного процесу, ведення адміністративної та господарчої діяльності. Наголосимо на очевидній для всіх нас аксіомі: необхідності формування професійно спрямованої іншомовної компетентності у майбутніх управлінців.

Висновки. Підсумовуючи вищевикладені судження стосовно означених аспектів проблеми управління науково-дослідної діяльності студентів в умовах магістратури, ми окреслили ряд важливих закономірностей.

По-перше, управління НДДС має двоконтурний характер. Перший контур - інтеграція науки і освіти, що поєднує виконання науково-дослідних робіт магістрантами 3 реальними потребами освітянських установ, другий контур - особистісно-мотиваційний компонент підготовленості майбутніх фахівців, що позитивно впливає на особистість майбутнього керівника загальноосвітнього навчального закладу.

По-друге, у цілісності, органічній єдності таких компонентів НДДС набуває відповідного змістового наповнення - слід віднайти й спрогнозувати нові акценти наукових розвідок.

Перспективи подальших досліджень вбачаємо у теоретичному осмисленні й уточненні базових понять і концептів нашої розвідки щодо управління науково-дослідною роботою студентів засобами інформаційно-комунікаційних технологій в умовах магістратури.

\section{СПИСОК ВИКОРИСТАНИХ ДЖЕРЕЛ ТА ЛІТЕРАТУРИ}

1. Про вищу освіту [Електронний ресурс] : Закон України від 01.07.2014 р. № 1556-VII : [редакція від 27.07.2017 p.]. - Режим доступу : http://zakon5.rada.gov.ua/laws/show/1556-18/page (дата звернення: 20.08.17). - Назва з екрана.

2. Про наукову і науково-технічну діяльність [Електронний ресурс] : Закон України від 26.11.2015 р. № 848VIII : [редакція від 01.01.2017 р.]. - Режим доступу : http://zakon5.rada.gov.ua/laws/show/848-19/page (дата звернення: 20.08.17). - Назва з екрана.

3. Про Державну національну програму "Освіта" ("Україна XXI століття") [Електронний ресурс] : постанова Кабінету Міністрів України від 03.11 .1993 р. № 896 : [редакція від 29.05.1996 р.]. - Режим доступу: http://zakon5.rada.gov.ua/laws/show/896-93-п (дата звернення : 22.08.17). - Назва $з$ екрана.

4. Лисенко С. А. Ставлення майбутніх магістрів військового управління в міжнародних відносинах до науководослідницької діяльності / С. А. Лисенко // Вісник Національного університету оборони України. Зб-к наук. праць. - К. : НУОУ, 2013. - Вип. 1 (32). - С. 88-92.

5. Шейко В. М. Організація та методика науково-дослідницької діяльності : [підручник] / В. М. Шейко, Н. М. Кушнаренко. - 6-те вид., переробл. і доповн. - К. : Знання, 2008. - 310 с.

6. Степашко В. О. Адаптивне управління науково-дослідною діяльністю студентів / В. О. Степашко // Освіта та педагогічна наука. - 2014. - № 1 (162). - С. 32-39.

7. Рогозіна М. Ю. Педагогічні основи самоосвітньої діяльності майбутніх учителів природничих дисциплін : дис. ... канд. пед. наук : 13.00 .04 / Рогозіна Марина Юріївна. - Донецьк, 2005. - 238 с.

8. Ніколаєва Л. Теоретичні аспекти науково-дослідницької діяльності студентів магістратури / Людмила Ніколаєва // Проблеми підготовки сучасного вчителя. - 2011. - № 4 (Ч. 2). - С. 178-184.

9. Балюк А. С. Особливості підготовки майбутніх магістрів гуманітарних спеціальностей до організації науково-дослідної діяльності / Анна Сергіївна Балюк // Наука і освіта. - 2015. - № 9. - С. 7-11.

10. Берека В. Є. Актуальні проблеми підготовки магістрів за спеціальністю "Управління навчальним закладом" / В. Є. Берека // Наука і освіта. - 2011. - № 7 (Педагогіка). - С. 8-10.

\section{REFERENCES (TRANSLATED AND TRANSLITERATED)}

1. Pro vyshchu osvitu [On Higher Education] [Elektronnyi resurs] : Zakon Ukrainy vid 01.07.2014 r. N 1556-VII : [redaktsiia vid 27.07.2017 r.]. - Rezhym dostupu: http://zakon5.rada.gov.ua/laws/show/1556-18/page (data zvernennia : 20.08.17). - Nazva z ekrana.

2. Pro naukovu i naukovo-tekhnichnu diial'nist [On Scientific and Technical Activity] [Elektronnyi resurs] : Zakon Ukrainy vid 26.11.2015 r. N 848-VIII : [redaktsiia vid 01.01.2017 r.]. - Rezhym dostupu : http://zakon5.rada.gov.ua/laws/show/848-19/page (data zvernennia: 20.08.17). - Nazva z ekrana.

3. Pro Derzhavnu natsional'nu prohramu "Osvita" ("Ukraina XXI stolittia") [On the State National Program "Education" ("Ukraine the $21^{\text {st }}$ Century")] [Elektronnyi resurs] : postanova Kabinetu Ministriv Ukrainy vid 03.11.1993 r. N 896 : [redaktsiia vid 29.05.1996 r.]. - Rezhym dostupu : http://zakon5.rada.gov.ua/laws/show/89693-p (data zvernennia : 22.08.17). - Nazva z ekrana.

4. Lysenko S. A. Stavlennia maibutnikh mahistriv viis'kovoho upravlinnia v mizhnarodnykh vidnosynakh do naukovo- 
doslidnyts'koi diial'nosti [The Attitude of Future Masters Specializing in Military Management of International Relations Towards the Research Activity] / S. A. Lysenko // Visnyk Natsionalnoho universytetu oborony Ukrainy. Zb-k nauk. prats' [National Defense University of Ukraine. Proceedings.]. - K. : NUOU, 2013. - Vyp. 1 (32). C. $88-92$.

5. Sheiko V. M. Orhanizatsiia ta metodyka naukovo-doslidnyts'koi diial'nosti [Organization and Methods of the Research Activity] : [pidruchnyk] / V. M. Sheiko, N. M. Kushnarenko. - 6-te vyd., pererobl. i dopovn. - K. : Znannia, 2008. - $310 \mathrm{~s}$.

6. Stepashko V. O. Adaptyvne upravlinnia naukovo-doslidnoiu diialnistiu studentiv [Adaptive Management of Students' Research Activities] / V. O. Stepashko // Osvita ta pedahohichna nauka [Education and Pedagogics]. 2014. - № 1 (162). - S. 32-39.

7. Rohozina M. Yu. Pedahohichni osnovy samoosvitnioi diial'nosti maibutnikh uchyteliv pryrodnychykh dystsyplin [Pedagogical Bases of Future Teachers of Natural Sciences Self-Education Activity] : dys. ... kand. ped. nauk : 13.00.04 / Rohozina Maryna Yuriivna. - Donets'k, 2005. - 238 s.

8. Nikolaieva L. Teoretychni aspekty naukovo-doslidnyts'koi diial'nosti studentiv mahistratury [Theoretical Aspects of the Master Students Research Activity] / Liudmyla Nikolaieva // Prolemy pidhotovky suchasnoho vchytelia [Problems of Modern Teachers' Training]. - 2011. - № 4 (Ch. 2). - C. 178-184.

9. Baliuk A. S. Osoblyvosti pidhotovky maibutnikh mahistriv humanitarnykh spetsial'nostei do orhanizatsii naukovodoslidnoi diial'nosti [Peculiarities of the Future Masters' of Humanities Preparation for the Research Activity Organization] / Anna Serhiivna Baliuk // Nauka i osvita [Science and Education]. - 2015. - № 9. - S. 7-11.

10. Bereka V. Ye. Aktual'ni problemy pidhotovky mahistriv za spetsialnistiu "Upravlinnia navchal'nym zakladom" [Currant Problems of Master Students' Preparation Specializing in Management of an Educational Institution] / V. Ye. Bereka // Nauka i osvita [Science and Education]. - 2011. - № 7 (Pedahohika). - S. 8-10.

\section{Гавриловский С. А. Научно-исследовательская деятельность будущих руководителей общеобразовательных учебных заведений в процессе магистерской подготовки: поиски новых возможнностей.}

На основании изучения теоретических источников по указанной проблеме исследования сделан обзорный анализ состояния научно-исследовательской деятельности будущих руководителей

общеобразовательных учебных заведений в условиях обучения в магистратуре; определень, а также изложены направления, задания, этапы организационно-педагогического сопровождения учебной и научно-исследовательской деятельности; выделены компоненты эффективного осуществления научноисследовательской деятельности магистров; обосновано значение и влияние личности научного

руководителя на успешность проведения научно-исследовательской деятельности будущих руководителей; из изложенных в статье суждений относительно исследуемой проблемы, нами были обозначены ряд важных закономерностей.

Ключевые слова: научно-исследовательская деятельность, научный руководитель, общеобразовательное учебное заведение, магистр, управление.

\section{Gavrylovskyi S. O. Scientific and Research Activity of Future Managers of Secondary Educational Institutions while Their Master's Degree Completion: Looking for New Prospectives.}

Modern system of higher education is shifting the priorities from traditional knowledge models towards humanitarian and personal. Thus it is prone to acknowledge the importance of every individual and seeks to create the atmosphere of creativity and mutual understanding between the participants of the educational process. Therefore, special attention is paid to the preparation of future managers of the secondary educational establishments to the research activity during their Master's Degree completion, since the personality of the manager influences the efficiency of the educational establishment functioning. One way to achieve this goal is effective organization of such work at higher educational establishments that combine educational and research activity of the students at every stage of their study. Taking into consideration that the problem under analyses has a complex nature, the search for new patterns of the master students' research work can be viewed relevant both

according to the content and the functional characteristics of the problem. That is why the aim of our investigation is to find and study new ways of research activity. Having studied scientific sources dedicated to

the problem under analyses, we suggest an overview of the research activity as provided by prospective managers of secondary educational establishments while their Master's degree completion. The article also highlights the ways, tasks and stages of organizational and pedagogical support of educational and research activity; it points out the components of effective research activity and indicates the degree of importance and influence of the scientific advisor's personality on the effectiveness of the student's research activity. Views, set forth in the article, give us way to name some important consistent patterns.

Key words: research activity, scientific supervisor, general educational institution, master's degree, management. 